\title{
Research on the Countermeasures and Approaches for Enhancing the Employability of Contemporary College Students from the Perspective of Ability-Guided Pattern
}

\author{
Xueshi Yan \\ Agricultural University of Hebei, Baoding City, \\ Hebei Province,071000 China
}

\begin{abstract}
In this paper, we conduct research on the countermeasures and approaches for enhancing the employability of contemporary college students from the perspective of the ability-guided pattern. In the case of rapid economic development, to solve the employment problem of college students, we must rely on the change of the college student employment concept and to increase the employment ability. Don't change concept, will be in the midst of intangible widening division of the labor market brought about by the imbalance of resource allocation and the available will make university students' employment into a vicious circle. In addition, the college students should improve their employment ability, employment ability is a comprehensive concept as includes the consciousness of employment, skills, abilities and comprehensive quality. Our article proposes the novel paradigm for the primary issues that is meaningful.
\end{abstract}

Keywords- Employability, College Students, Ability-Guided Pattern, Countermeasures.

\section{Introduction}

University students' employment has become a hot problem of the current society, because it not only relates to the graduates themselves, also involves the family, and the whole country, and therefore, to solve this problem properly and is about the overall situation of the social stability and development. This paper briefly explains the economic structure in our country on analyses the current employment situation, from the

\author{
Bo Ma \\ Agricultural University of Hebei, Baoding City, \\ Hebei Province,071000 China
}

perspective of social macro and puts forward some of suggestions on the college students' own ability construction.

According to the literature review, currently, the primary challenges for the student employability could be generally summarized as the follows. (1) Lack of self-knowledge and employment planning. Most college student lack of understanding of the society, as there is almost no internship experience, focusing on theoretical knowledge learning in school, plus the school did not start the related courses about career planning. (2) Know the job skills. Job needs to be in the shortest possible time to show their best side, with beautiful resume packaging themselves, through effective communication to unit of choosing and employ persons to understand. Most college students lack the skills to apply for a job, although during the period of school has accumulated profound theoretical knowledge, but not in the correct way to show unit of choose and employ persons, led to the talent, and hard to found by bole, and so on and so forth. (3) Education mode is not adapted to the needs of society. Education of most colleges and universities still education is given priority to, the lack of the professional education and practical education, cultivate college students' talent makes only master the theory knowledge, and practical ability is insufficient, and social derailment with not knowledge. (4) Professional settings do not conform to the social needs. College in the professional settings prior to the needs of society, the social need of professional is not set and the output of a large number of 
talents does not adapt to the needs of social development that caused the waste of resources [1-2].

Jobs can make students with high quality people participate in economic construction. In different stages of economic development, puts forward the different levels of requirements for workers. The development of our country's economy urgently needs a large number of high-level personnel. China's economic growth mode from initial extensive to intensive, fostering a large number of high levels of production, management, service personnel as determinants of the economic growth of science and technology is mastered by human resources, human resources, the higher the level of science and the technology, the more the number, the faster the speed of technological innovation, to the greater role in promoting economic development. Under this prerequisite, we list the corresponding keywords for the employability principles in the figure one [3-4].

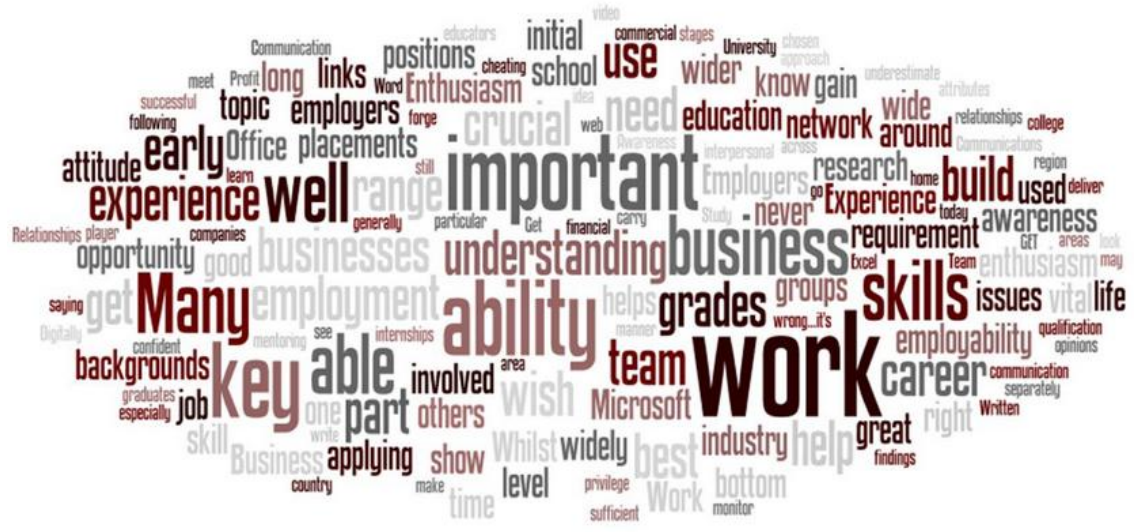

Figure 1. The Keywords of the Employability

In this paper, we conduct research on the countermeasures and the approaches for enhancing the employability of the contemporary college students from the perspective of the ability-guided pattern. Modern vocational education is not in training by the work "the slaves, but cultivate the owner of the occupation, keen on innovation and therefore, the purpose of the vocational education is not only for economic and social development of the "human", respect people's value, the development of each person's potential is the ethical mission of the vocational education, it is in line with the humanitarian education standards, the impartiality of education policy guidelines and respect natural environment and cultural diversity of connotative development needs. In the following sub-sections, we will show our novel perspective and methodology on the corresponding issues.

\section{Our Proposed Methodology and Perspective}

The Ability-Guided Pattern. The problem oriented type teaching take the student as the main body, problem oriented, and its ultimate goal is to cultivate students' ability of thinking and the independent thinking while problems in teaching practice guiding type teaching method can largely overcome the defect of traditional teaching method, make to effectively cultivate students' thinking and independent thinking ability, knowledge and skills to the internalize, it also very harmonious relationship between teachers and students. At the same time, the problem oriented type teaching method is particularly the suitable for small class teaching of specialized course teaching. Action-oriented teaching is teachers according to the requirements of corresponding professional action select teaching methods, design the 
teaching activities, evaluation of the teaching process to achieve the established education target, a series of principles including one of the most core principles.

- The principle of reflective. The principle requires vocational education teaching activities to the students in the social life and real experience in professional practice as the starting point. In the teaching situation, teachers to organize and guide students to review and analyze their life experience, or professional practice to check and judge character of cognitive judgment and corresponding strategies form and expand vocational ability to act.

- Integrity principle. Complete working process including consulting design, implementation of a monitoring in decision making, six steps only involved in the complete process, students can gradually form required for professional practice of social belonging, general responsibility consciousness, creative and professional ability of continue development foundation [5].

- Contextualized principle. This principle requires students in true or accurate real professional practice situation and complete formal requirements to actions in the meet the requirements of quality, economy, and ecology work, obtained formed the experience of vocational ability. In order to facilitate migration implementation experience and ability which require the teaching situation and professional situation relatively consistent in terms of the structure.

According to the capacity of nature can be divided into basic professional ability and professional ability of the key ability. Basic professional ability is essential for workers engaged in a professional capacity which is the core of the worker work career, survival skills, including individual skills and the knowledge, comprehensive skills and the knowledge. Key ability refers to the student to obtain to complete the task and future development of change should obtain cross-functionally, multifunctional and is not restricted by time and have overcome aging knowledge and the ability of basic continuous learning for the future life. Basic professional ability is for a professional or professional group and the key vocational ability is general ability, pay attention to individual career development, is for all classes. For vocational education as divided into the two different ability means that can be designed according to the nature of education and training courses with the implementation of teaching.

The ability-guided pattern could be generally summarized as the following aspects. (1) Teachers explain basic theory. Although problem oriented type teaching take the student as the main body, but the teacher's explanation is also indispensable, namely before the formal problem set and discussion, the teacher needs to be involved in the problems about basic theory to students. (2) The teachers and students set problem. With the traditional teaching method is different and the problem oriented type teaching problem oriented. After being teachers should know the basic theory of interpretation, the next to be is a question. At the same time, teachers guide students to ask questions, to closely around the theme. (3) Discussion and communication between teachers and students. Summary of the link is for all the questions and the answers to these questions system comprehensive combing, clear profit and loss of the research. In carding process, the need to clear what problems have been completely resolved, what problem that has not been completely solved and if not completely, it is necessary to summarize the reason. Only after a summary, can clear learned what knowledge, mastered the skills, understand what truth, received what effect also what deficiencies and lack of need further exploring. 


\section{The College Students' Vocational}

Education. Education is the education that through education makes a person become a useful person is the fundamental aim of education. The fountain of the technology and education is the demand of human society. Therefore, education and technology are common development and common growth both of the characteristics of the human society activities, and accompanied by career choice and positioning. Education development is needed in the process of technology, or is able to function in education as it is because the education object of study and the technology there is a common theme.

Although enterprises participate in vocational education restricted by many factors, but its "use" the "production" school students, this determines the vocational education responsibility, as not only does it not throw away the opposite should be positive to face and bear, seeking university-enterprise cooperation between the balance. How to build "compact" innovation and basic development path, collectivize school-running mode, to promote the new development of vocational education group is of great significance that we show the countermeasures as the follows [6-7].

- The innovation collectivizes school-running core mechanism. Introducing market mechanism, to further broaden the collectivization school-running channels of financing. Private capital and private vocational colleges and universities should be brought into the collectivization, the union school, increase pace of industrialization of vocational education collectivization school-running, introducing modern management system, to raise the scale and control school fees, increasing the service efficiency of education funds and implement the industrialization operation with further improve the capacity of the vocational education.

- Construct collectivize school-running cluster value chain. Vocational education cluster value chain operations, can effectively will participate in collectivization school-running "bundling" mix, optimizing collectivization school-running ecosystem, promote the capital, technology and information resources sharing, and form the collectivization of running a school can be made use of value-added model plays an important role.

- The collectivization school-running market response system that is established. Vocational education should take the market demand as the core, and linked to the regional economic characteristics, industrial structure adjustment, docking and regional economy development of coexistence and co-prosperity. From the professional structure, to fit the market demand, further eliminate major setting and talent demand structural contradiction, play to the role of market strain system, with keen perspective focus on the future direction of regional economic development and rising sun industry to make professional real docking industry. 


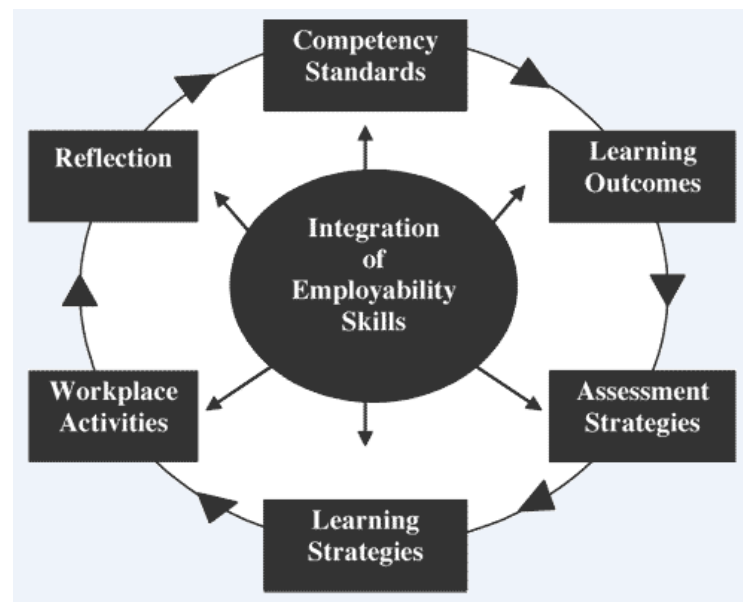

Figure 2. The Developmental Circle of the College Students' Vocational Education

\section{The Countermeasures and Approaches for} Enhancing Employability. In order to speed up the economic development, adjust industrial structure upgrade in our country and it involves economic issues, and the employment of college students related to the social problems, they belong to different fields, but it is closely linked. Different industry demand for labor will be different, qualities and skills requirements for labor will be different so the change of industrial structure will inevitably cause the employment structure change, college students as the main force of labor as the employment is bound to be along with the general change.

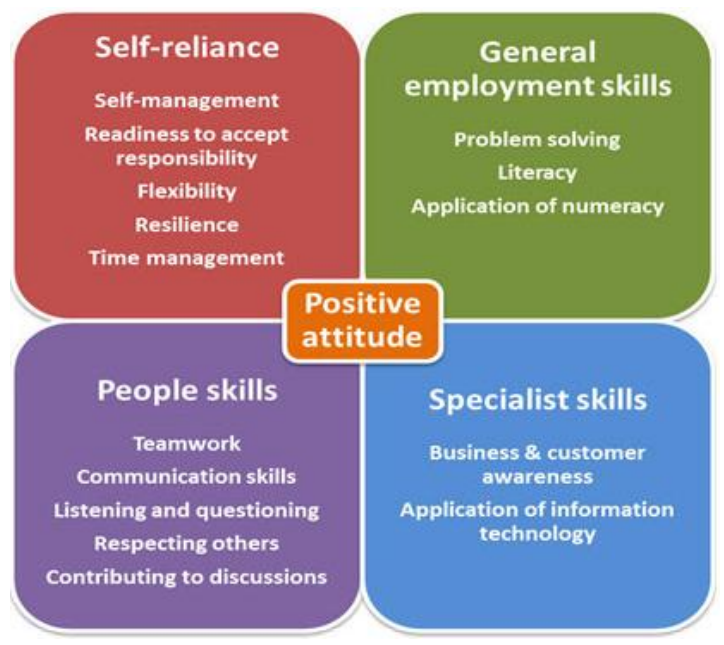

Figure 3. The Principle Points of the Employability Approaches
As shown in the figure three, we define the principle points of the employability approaches. Based on the guidelines, we should enhance the student employability from the listed perspctives. (1) The survival skills, training and exercise. Introduce the concept of survival employment guidance work, the purpose is to make students through skill training to the life, society, survival is more clear, thus learning life, learn to live and learn to better get along with people and learn survival skills. (2) Set up the concept of life-long study, ease students survival crisis. Students set up the concept of lifelong learning, constantly updated knowledge and ability, to catch up with the progress of society to make it better able to survive. (3) Information technology updated quickly in today's society, college students get the amount of information is also very big. Information of fast denaturation that makes students overwhelmed, network virtual property and easy to cause the students to apply for. Therefore, from the point of view of adaptability education, students should strive to update information age survival concept, through the system of learning and general practice training enable students to master certain information acquisition and filtering ability to make students get information behavior norms, etc., at the same time can effectively promote students' ability of objective evaluation information ability.

\section{Conclusion}

In this paper, we conduct the research on the countermeasures and the approaches for enhancing the employability of the contemporary college students from the perspective of the ability-guided pattern. Economic development is often easy to cause the great changes in social professional demand for the talent, some new career due to adapt to the social development demand, the demand for the talent increases sharply, cause the talented person, formed the so-called hot jobs, and some of the traditional career because of already can't adapt to the development of society, economy and slowly 
shrink, or even disappear. The hot jobs as a result of talent tend to have better economic benefits and therefore, most of them will become the main target of the college students' employment. Our research starts from the discussion of the corresponding challenges to provide the countermeasures that will enhance the general ability success rate that is meaningful.

\section{Acknowledgement}

This paper is financially supported by the following projects. (1) Philosophy and social sciences of Baoding city planning research project: Research on the effective methodologies for college helped push the rooting process of socialist core values in Baoding (NO. 20140244). (2) The development of social science research project in the Hebei province: The Beijing-Tianjin-Hebei background of the development of agricultural cooperation of agriculture and forestry colleges and universities talents cultivation orientation (NO. 2015030457). (3) Ideological and political work of Baoding city research subject: Campus culture brand building practice of socialist core values with the concept of good stories in agricultural university (NO. BDSZYH006).

\section{References}

[1] Senior, Carl, Peter Reddy, and Rowena Senior. "The relationship between student employability and student engagement: working toward a more unified theory." Frontiers in psychology 5 (2014).
[2] Arrowsmith, Colin, et al. "Student employability and its implications for geography curricula and learning practices." Journal of Geography in Higher Education 35.3 (2011): 365-377.

[3] Cui, Suxia. "Research on the Improving Path of College Student Employability from Social Practice Perspective." Journal of Applied Science and Engineering Innovation Vol 2.3 (2015): 81-83.

[4] Lin, Mei-Chin, and G. S. Ching. "College student'employability: Implications of part-time job during college years." Advances in public, environmental and occupational health 4 (2014): 101-106.

[5] Dacre Pool, Lorraine, Pamela Qualter, and Peter J. Sewell. "Exploring the factor structure of the CareerEDGE employability development profile." Education+ Training 56.4 (2014): 303-313.

[6] O'Leary, Simon. "Impact of entrepreneurship teaching in higher education on the employability of scientists and engineers." Industry and Higher Education 26.6 (2012): 431-442.

[7] Jarvis, Joy, Claire Dickerson, and Lewis Stockwell. "Staff-student partnership in practice in higher education: the impact on learning and teaching." Procedia-Social and Behavioral Sciences 90 (2013): 220-225. 